\title{
EDITORIAL
}

\section{La bioética como brecha}

Por: María Luisa Pfeiffer ${ }^{1}$

La bioética, los bioeticistas tienen un desafio, el de abrir una brecha por donde comiencen a fluir los derechos para todos los hombres. Para ello su primera y fundamental actitud es la de reconocer que quienes acompañan al proceso globalizador usan sus mismos conceptos para sostener la situación de dominio: hablan de autonomía por ejemplo, mostrando cómo los individuos pueden decidir por sí mismos cumpliendo con ciertas condiciones que tienen que ver sobre todo con el conocimiento; hablan de libertad condicionándola a una situación de independencia absoluta imposible ni siquiera de pensar y reduciéndola finalmente a una elección entre opciones puestas por el sistema; hablan de derecho como reivindicación de los deseos de cada uno; de solidaridad como dádiva de los que tienen a los que no tienen; de dignidad como autoestima; de justicia como modo de reparto de bienes. Lo que tenemos que aprender los bioeticistas es que lo que se juega en la bioética y en la ética en general tiene que ver con los significados. Es decir con los contenidos de las palabras y de los actos, con el sentido de las conductas, y sobre todo con el valor de las decisiones.

Esto significa que debemos aceptar que el único modo de generar y agrandar la brecha es pensando y poniendo en acto una bioética desde Latinoamérica reconociendo que desde este continente se ha consolidado la relación entre bioética y derechos humanos5. Esa relación se encuentra en plena elaboración como idea rectora de las reflexiones, que, como tal, es expresión de los valores que tanto individuos como grupos sociales reconocen pero que aún no tiene vigencia ni en los usos, ni en la educación, ni en la moda. Recordemos que "cultura y sociedad mantienen una relación generadora y en esta relación son fundamentales las interacciones entre individuos que son, ellos mismos, portadores y transmisores de cultura: estas interacciones regeneran a la sociedad, la cual regenera a la cultura" (Morin, 1992). Hemos de crear una nueva cultura y una nueva sociedad trabajando en común sobre conceptos que nos permitan pensar en otra bioética, en otra manera de plantear la ética y la política, en valores propios de nuestra región que puedan ser reconocidos por otras regiones6 (Tealdi, 2008). Debemos comenzar por el concepto de dignidad como expresión del reconocimiento plural que debe darse entre individuos y pueblos; el concepto de historia como proyecto colectivo reivindicador de la igualdad y la solidaridad sostenida sobre la práctica del don, de la gratuidad; el concepto de libertad como proceso de emancipación de los poderes dominantes, fundamentalmente el económico; el concepto de justicia asociado a la igualdad como única garantía de la paz.

Todo lo anterior debe ir acompañado de una comprensión integral del ser humano, donde su corporalidad sea la protagonista de sus derechos, de tal modo que lo que estos reivindiquen sea una identidad que vaya de la mano de la integridad, un ejercicio de la palabra que tenga valor simbólico y operativo, una convivencia comunitaria que se construya alrededor de la solidaridad y no de la competencia.

\footnotetext{
Licenciada en Filosofia, Facultad de Filosofia, Universidad del Salvador, Bs As, 1962-1967. Doctora en Filosofia, Universidad de la Sorbonne, Paris, 1976. Tema: "Vers 1'Etre Brut. La contingence chez M. Merleau-Ponty". Jurado J.Jankélevich, O. Lacombe, I Belaval, director de la tesis J. Wahl. Docente y codirectora del curso de especialización en Bioética y Derechos Humanos organizado por el Comité de Bioética del Htal. Nac. Marie Curie, abril-julio 2012. Docente del curso de doctorado "Introducción a la bioética", en el doctorado de la Universidad del Bosque, Bogotá (Colombia).
} 
Construir esta bioética implica pensar en el derecho a la salud desde una visión latinoamericana de la salud que implica la recuperación del ocio, de la fiesta, de la religiosidad, de la vida comunitaria, de la cultura como marco vital donde presente, pasado y futuro pertenecen al mismo movimiento; de la vida con memoria, del amor y respeto por la naturaleza, de la comida como re-unión con los otros y no como mero alimento, de la muerte como posibilidad de encuentro con el misterio de la vida, de la trascendencia, dando sentido a la historia. La bioética será entonces la ética del bios, de la vida humana en todas las expresiones que permiten llamarla humana.

Ya no se preguntará por una muerte digna sino por una vida digna, nadie muere indignamente si ha vivido con dignidad puesto que ésta tiene que ver con el reconocimiento de los otros. Es posible considerar que los enfermos no mueran dignamente cuando les robamos su propia muerte, por ejemplo, dejándola solamente en manos de médicos que se afanan por prolongar indebidamente la vida por medios técnicos o de equipos médicos que desconocen tato al enfermo y su voluntad como a la familia que es el espacio donde el enfermo ha construido su vida. Una muerte indigna es la que acaece en un medio donde se ignora el conocimiento del enfermo que tienen la familia y los amigos; se decide en lugar de ella o se la empuja a decisiones incorrectas que ignoran la posibilidad y necesidad de que cada enfermo, cada ser humano, se reconozca en su finitud, en su condición de mortal. Ello obliga al enfermo y a su entorno a la mentira, el disimulo, el engaño, insistiendo en prácticas que sólo causan daño y ningún beneficio, sin dialogar, sin permitir al enfermo usar de la palabra, expresar sus valoraciones, proyectar un futuro sea éste de minutos, horas o meses. La bioética es, en muchos casos, instrumento globalizador cuando decide que el enfermo debe morir en su casa y arma alrededor de ello todo un aparato ideológico sin preguntar a la familia y al mismo enfermo cuáles son las condiciones en que el enfermo podría estar en su casa, si él lo desea realmente, si lo desea la familia, si aún deseándolo puede, si es necesario ayudar a las familias que quieren pero no pueden. Es tan globalizador como cuando la medicina intervencionista a ultranza convence al enfermo y a la familia que el mejor lugar para esperar la muerte es el hospital porque allí será atendido a toda hora y podrán intervenir sobre él ante cualquier emergencia. Cuando la historia y la circunstancia del enfermo es ignorada se le está mancillando su dignidad, cuando su lenguaje es ignorado, su palabra es menospreciada, sus expresiones desconocidas, su dignidad también lo es.

Y pensar sobre la muerte digna, poniendo el acento sobre el adjetivo, nos obliga a pensar una vida digna y en consecuencia a rechazar todo lo que la globalización identifica con vivir y morir. El poder económico globalizador se empeña en que la muerte desaparezca, sea vendiendo aparatos y drogas cada vez más perfectas para evitar la muerte, sea generando expectativas de que la muerte será derrotada, por lo menos las pequeñas muertes por ahora ya que la gran muerte, la definitiva parece ir ganando la partida; sea propiciando que nadie vea a los moribundos, que nadie los escuche, que los duerman y los mantengan dormidos, que los aíslen para que no causen impresión, dolor, asco, rabia, desesperación, angustia. Todos estos sentimientos deben ser desterrados, cambiados por una anomia que frente al moribundo sólo espera que muera pronto para retomar la vida habitual, el trabajo productivo, para olvidar rápidamente que también moriremos, o mejor aún que morimos permanentemente. Si lo olvidamos creeremos en la promesa globalizadora de la felicidad eterna, la juventud eterna, la vida eterna. Para ello producen, compran y venden los países, para ello somos vigilados y controlados por redes virtuales, para ello somos atendidos globalmente por una medicina globalizada que se ocupa de enfermedades y no de enfermos, para ello somos educados siguiendo programas globales, para ello trabajamos siguiendo planes globales.

La bioética, o mejor los bioeticistas, tenemos un compromiso con el presente y el futuro, del mismo modo que pensamos la dignidad en relación con el momento del morir debemos pensarla en relación con el momento del nacer, del crecer, del vivir como adulto y como anciano, de las condiciones de la vida tanto económicas, como políticas, como ambientales. Ya Potter lo adelantó cuando habló del puente hacia el futuro, idea que luego fue olvidada enredando las conductas alrededor de pseudo problemas. Hemos escrito libros y libros estableciendo condiciones para la autonomía, más aún de las que el mundo actual le impone y sin reconocer estas últimas: la pobreza que no es sólo material, la marginación que no es sólo intelectual, el trabajo como alienación, la ciencia como avanzada de dominación, la publicidad como conformadora de la moral y finalmente la globalización como un modo de negar la identidad y con ella la integridad. La autonomía, el consentimiento informado, terminan 
convirtiéndose en artilugios que usan muchos bioeticistas para centrar los discursos en problemas particulares como son la relación médico-paciente que si bien no son despreciables deben insertarse en los verdaderos problemas que tienen que ver con los derechos y la justicia.

Estas cuestiones como las que enaltecen la labor médica en pos del triunfo sobre la vejez, la enfermedad y la muerte impulsan, a veces sin saberlo ni quererlo, el modelo liberal en las relaciones y del neocapitalismo en la concepción de la salud. Al naturalizar la escasez de recursos en salud, se ocultan los problemas estructurales de los sistemas sanitarios, y de la relación con el ambiente y se distorsiona toda decisión política.

No podemos seguir engañando y engañándonos, tenemos un desafio y no podemos renunciar a él, el de abrir una brecha en esta cultura invasora que nos hace olvidar que significa ser un hombre. 



\section{EDITORIAL}

\section{Bioethics as a breach}

By María Luisa Pfeiffer ${ }^{1}$

Bioethics, and bioethicists especially, has a challenge which is to open a gap through which the rights for all men can flow smoothly. So their first and fundamental attitude is to recognize that those who accompany the globalization process use the same concepts to hold the status of domain: for instance, they talk about autonomy, showing how individuals can decide for themselves, complying with certain conditions that have to do with knowledge. These talk about freedom making it conditional to a situation of absolute independence, which is impossible even to think about and finally bringing it down to a choice among options placed by the system. These refer to law as a vindication of each individual's wishes. These conceive solidarity as a gift for those who have to those who do not have; of dignity as selfesteem; of justice as a mode of distribution of goods. What we, as bioethicists, have to learn is what is played in bioethics and ethics, in general, which has to do with the meanings. That is to say, with the content of words and acts, in the sense of behaviors, and especially with the value of decisions.

This means that we must accept that the only way to build and to enlarge the breach is thinking, and putting into action a bioethics from Latin America recognizing that from this continent, the relationship between bioethics and human rights has been consolidated. That relationship is in full development as a guiding idea of reflections that, as such, is an expression of the values that both individuals and social groups recognize, but which has no validity in applications, or in education, or in fashion yet. Let us remember that "culture and society have a generating relationship and the interactions among individuals who are, themselves, carriers and transmitters of culture are fundamental in this relationship: these interactions regenerate society, which regenerates culture" (Morin, 1992). We have to create a new culture and a new society, by working together on concepts that allow us to think in another kind of bioethics, in another way of raising the ethics and politics, in values proper to our region can be recognized by other regions (Tealdi, 2008). We must begin with the concept of dignity as an expression of plural recognition that must occur among individuals and peoples; the concept of history as a vindicating collective project of equality and sustained solidarity upon the practice of gift and gratitude; the concept of freedom as the process of emancipation of the dominant powers, primarily the economic one; the concept of justice associated with equality as the only guarantee of peace.

All of the above must be accompanied by a comprehensive understanding of the human being, where his physicality is the protagonist of their rights, in such a way that what they claim is an identity that will go hand in hand with integrity, an exercise of the word that has a symbolic and an operational value; that is to say, a community coexistence that is built around solidarity and not on competition.

The construction of this type of bioethics involves thinking about the right to health from a Latin American perspective on health involving the recovery of leisure, of party, of religiosity, of community life, of culture as a vital framework where present, past and future belong to the same movement; of life with memory, of love and respect for nature, of food as a re-union with others and not mere food; of death as a possibility of encounter with the mystery of life, of the importance, giving meaning to history. Bioethics will then be the ethics of bios, of human life in all the expressions that let it be called human.

It will no longer ask for a dignified death, but for a dignified life. Nobody dies unworthily if they have lived with dignity since this has to do with the recognition of others. It is possible to consider that patients

Licenciada en Filosofia, Facultad de Filosofia, Universidad del Salvador, Bs As, 1962-1967. Doctora en Filosofia, Universidad de la Sorbonne, Paris, 1976. Tema: "Vers l'Etre Brut. La contingence chez M. Merleau-Ponty". Jurado J.Jankélevich, O. Lacombe, I Belaval, director de la tesis J. Wahl. Docente y codirectora del curso de especialización en Bioética y Derechos Humanos organizado por el Comité de Bioética del Htal. Nac. Marie Curie, abril-julio 2012. Docente del curso de doctorado "Introducción a la bioética", en el doctorado de la Universidad del Bosque, Bogotá (Colombia).maria3729@hotmail.com 
cannot die with dignity when we steal them their own death, for example, leaving them only in the hands of doctors, who are just worried about prolonging their lives unduly, by technical means or by medical teams, who are unaware of both the sick people, their will and their families, which is the space where the patients have built their lives. An undignified death is the one that happens in an environment in which the knowledge of the patient is ignored, which is possessed by family and friends. Somebody else is the one who decides by them or they are pushed to make wrong decisions by ignoring the possibility and need that every sick person has, so every human being can be recognized in their condition of finitude, in their condition of being mortal. This forces the sick people and their surroundings to lie, concealment, deception, insisting on practices that only cause them harm, from which they do not get any benefit, without dialogue, without allowing the patient to take the word, expressing their assessments, planning a future consisting of minutes, hours, or months. Bioethics is, in many cases, a globalizing tool when it decides that the sick person should die at home and this builds up an ideological apparatus, without taking into consideration the patients themselves and their families as for the conditions in which the sick people could be at home. In other words, if they really want to, if their families want to, or if they are willing to do so, they really can, and even if it is necessary to the families who want to, but they cannot. It is so comprehensive when it comes to the interventionist medicine at any prize convinces the sick people and their families that the best place to await for death is the hospital, they will be looked after around the clock, and they will be intervened, in case of an emergency. When history and the circumstances of patients are ignored, their dignity is being tainted, when their language is ignored, their word is despised, and when their expressions are disregarded, so is their dignity.

And the fact of thinking about a dignified death, putting the accent on the adjective, makes us think about a worthy life and consequently reject everything that globalization identifies with life and death. The globalizing economic power insists that death disappears, whether selling appliances or developing more and more suitable medications to prevent death, by generating expectations that death will be defeated, at least, the small deaths so far, since the great death, the ultimate one seems to be winning the game; by encouraging anyone to see the dying, where no one hears them, and they are kept asleep, and that they are isolated so that they do not cause any impression, pain, disgust, anger, despair, or anguish. All of these feelings must be banished, replaced by an anomie that regarding the dying only expects him to die soon in order to take up again a normal life, a productive work, to quickly forget that we will also die, or even better that we are permanently dying. If we forget it, then we will believe in the comprehensive promise of eternal happiness, eternal youth, and eternal life. For this purpose, countries produce, buy, and sell products or services, so we are under close surveillance and controlled by virtual networks. That is why we are globally looked after by comprehensive medicine dealing with diseases and not with the sick people, so we are educated according to global programs, so that we can work in accordance with global plans.

Bioethics, or even better, bioethicists have a commitment to the present and the future, in the same way that we think the dignity in relation to the time of death. We should think it in connection with birth, growing up, and living as an adult and as an elder, as for the economic, political, and environmental living conditions. Potter has already mentioned it when he talked of the bridge to the future, an idea which later on was then forgotten, entangling behaviors around pseudo problems. We have written books, books about the conditions for the establishment of autonomy, even more by those imposed by the current world and without acknowledging the latter: the poverty that is not only material, the marginalization that is not only intellectual, the work as alienation, since as advanced domination, advertising as a form of morality and finally globalization as a way of denying the identity and integrity. Autonomy and informed consent end up becoming contraptions that many bioethicists use to focus their speeches on particular issues such as the doctor-patient relationship, that while they are not despicable, they should be inserted in the real issues that have to do with the rights and justice.

These issues as those which highlight the medical work in pursuit of triumph over old age, disease and death, drive, sometimes without knowing it or wanting it, the liberal model in relations and neocapitalism in the conception of health. By naturalizing the scarcity of resources in health, the structural problems of health systems are hidden, and the relationship with the environment and any political decision is distorted.

We cannot keep fooling and deceiving ourselves. We have a challenge, and we cannot give it up. It consists of opening a gap in this invasive culture that makes us forget what it means to be a man. 